\title{
骨肉腫の肺転移についての検討
}

\author{
鳥取大学医学部整形外科 \\ $\begin{array}{llll}\text { 豊 島良 太・前 山 } & \text { 璇 } \\ \text { 池 本 和 人・大 } & \text { 廻 } & \text { 游 }\end{array}$
}

\section{Some Investigations on Pulmonary Metastasis of Osteosarcoma}

By

\author{
R. Teshima, I. Maeyama, K. Ikemoto \& Y. Osako \\ Department of Orthopaedic Surgery, Tottori University \\ School of Medicine
}

\begin{abstract}
The volume doubling time and tumor duration time of pulmonary metastatic nodules in our fifteen cases of osteosarcoma were calculated by Collins' chart and Wollin's formula.

Results were as follows.

1. The volume doubling time of osteosclerosing osteosarcoma was generally longer than that of osteolytic osteosarcoma.

2. The chemotherapy for pulmonary metastases prolonged their volume doubling time remarkably.

3. The tumor duration time was ranged from 0.86 to 8.15 years (average 3.32 years). It was suggested that the metastasis of osteosarcoma to the lung might be 2.7 years in average prior to the onset of symptoms of primary lesion.

4. Regarding the growth rate of pulmonary metastases of our cases, the Collins' hypothesis seemed to be considerably acceptable.
\end{abstract}

骨肉腫は早期根治治療にもかかわらず，その予後は きわめて不良である．との原因の多くは，骨肉腫の血 行性転移一とくに肺転移にあり, 骨肉腫治療の鍵は, 肺転移の成立防止・肺転移巣の発青抑制に求めらるへ きであろう．今回，肺転移をきたし，胸部エックス線 写真の比較的整っている骨肉腫15症例を対象とし, 1) 肺転移巣の形態およびその分布状態，2）肺転移結節 の体積倍增時間 volume doubling time (VDT), 腫 煬持続時間 tumor duration time (TDT) の測定,

3）治療の有無によるVDT の変動，4）原発巣エッ クス線像と VDT の関連性, について検討を加えたの で報告する。

\section{調 查 対 象}

昭和 29 年から昭和 48 年までに当教室で経験した骨 肉腫 28 例のうち, 肺転移をきたし, 経時的に胸部エ ックス 線写真にて 観察可能な 15 症例を対象とした. 全症例とも，すでに死亡しており，男 8 人，女 7 人
で, 発病時年齔は平均 16.2 才 (10〜28才)である. 骨肉腫原発部位は, 大腿骨遠位部 9 症例, 脛骨中枢部 5 症例, 腓骨中权部 1 症例で, そのエックス線像は 9 症例が造骨性 osteosclerotic type，6症例が溶骨性 osteolytic type である.

肺転移に対し化学療法をまったく施行していない 2 症例, ならびに短期間単独に抗癌㓮を使用したにすぎ ない 4 症例（表 1, No. 1～No. 6 症例）を化学療法 非施行群とみなし, 長期間皘極的に化学療法を施行し た9症例（表 1，No. 7〜 No. 15）を化学療法施行群 と考えた. 1 例（表 1 , No. 6 症例）は初晾時より肺 転移を認めたので原発巣試験切除のみにとどめ, 他の 14 例はすべて患肢の切断を施行している.

\section{調 查方 法}

胸部エックス線写真をさかのぼり，不整形または部 分的に隱蔽された転移結節を除き, 類円形・正円形の 転移結節の最大径を求め, Collins の Chart, Wollin 
表 1 症 例 一 筧 表

\begin{tabular}{|c|c|c|c|c|c|c|c|}
\hline$N_{0}$ & 在 & 列 & 原器部位 & 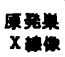 & V D T & 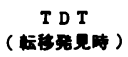 & 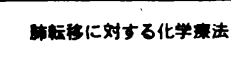 \\
\hline $\begin{array}{l}1 \\
2 \\
3 \\
4 \\
5 \\
6\end{array}$ & $\begin{array}{l}10 才 \\
15 \\
14 \\
19 \\
17 \\
14 \\
\end{array}$ & $\begin{array}{l}\text { 女 } \\
\text { " } \\
\text { 男 } \\
\text { 女 } \\
\text { " } \\
\text { " }\end{array}$ & 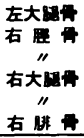 & 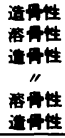 & $\begin{array}{l}21 日 \\
18 \\
23 \\
20 \\
17 \\
29 \\
\end{array}$ & $\begin{array}{l}1.52 \text { 年 } \\
1.26 \\
1.64 \\
1.43 \\
1.29 \\
2.15 \\
\end{array}$ & $\begin{array}{l}\text { Sarcomycin } \\
\text { N1trom1n } \\
\text { " } \\
\text { copp }\end{array}$ \\
\hline
\end{tabular}

\begin{tabular}{|c|c|c|c|c|c|c|c|}
\hline $\begin{array}{r}7 \\
8 \\
9 \\
10 \\
11 \\
12 \\
13 \\
14 \\
15\end{array}$ & $\begin{array}{l}17 \\
13 \\
16 \\
14 \\
16 \\
28 \\
14 \\
15 \\
16\end{array}$ & $\begin{array}{l}\text { 男 } \\
\text { 女 } \\
\text { 勇 } \\
\text { " } \\
\text { " } \\
\text { ' } \\
\text { 女 } \\
\text { 男 } \\
\text { " }\end{array}$ & 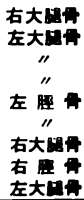 & 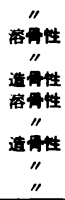 & $\begin{aligned} 104 \\
47 \\
28 \\
50 \\
29 \\
56 \\
121 \\
108 \\
15\end{aligned}$ & $\begin{array}{l}7.88 \\
3.59 \\
2.08 \\
3.86 \\
2.10 \\
3.91 \\
8.15 \\
8.05 \\
0.86\end{array}$ & $\begin{array}{l}\text { Azan, Sarcomycin, Nitromin } \\
\text { MMC. Mothotroxato. TY } \\
\text { EX. TY } \\
\text { MMC. } 5 \text { Fu } \\
\text { VAMT } \\
\text { VAMT. EX } \\
\text { VANT. EX. } 5 \text { Fu. CQ } \\
\text { VANT. EX. CQ } \\
\quad \text { "I }\end{array}$ \\
\hline
\end{tabular}

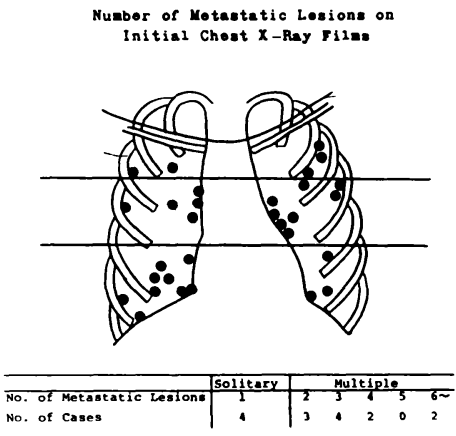

図 1

の数式より VDT·TDT を算定した.

\section{結果}

肺転移は切断施行後ほぼ 6 力月以内に発見されるて とが多く, 肺転移発見後 1 年以内にその 8 割以上が死 亡している。

胸部エックス 線写真をさかのぼって検討してみる と, 肺転移結節は発見時では, 中肺野以下に 1 個もし くは 4 個以下の少数性に現れ，その形状は星状もしく は雲絮状の不整形陰影を呈し，その径は $0.5 \mathrm{~cm}$ から $1.0 \mathrm{~cm}$ の範囲にあるものが多い（図 1). 臨床上, 肺 転移結節発見時の径はほぼ $1.0 \mathrm{~cm}$ 以上であり，ての ため $1.0 \mathrm{~cm}$ 以下の転移結節は臨床的には見過される ととがきわめて多いものと思われる. No.13, No. 14 の症例は再検討の結果, 切断前にすでに肺転移の存在 が決定された症例である。

肺転移発現については, 肺野の左右差は認めず，転 移結節は発見時には不整形，かつ辺縁不鮮明である が，径の増大とともに類円形もしくは正円形となり， 辺縁も鮮明化する．末期には，さらに増大するにつれ， 肺炎の併発, 胸水などのため, 転移結節は曖蔽され, 計測は不可能な状態になりがちである.

VDT·TDT は表1亿総括したとおりである.すな わち化学療法非施行群 6 症例の VDT は最小 17 日, 最大 29 日, 平均 $21.3 \pm 4.3$ 日であったが，化学療法施 行群 9 症例においては, 最小 15 日, 最大 121 日, 平均 $62.0 \pm 39.1$ 日であった。肺転移発見時までの TDT は, 化学㙩法非施行群で最短 1.26 年から最長 2.15 年, 化学療法施行群で最短 0.86 年から最長 8.15 年の值を とった. 化学療法施行群の VDT.TDT は, 非施行群
に比べ著しく延長している.

つぎに原発巣エックス線像についてみると，osteosclerotic type の 9 症例の VDT は, 最小 15 日, 最 大 121 日，平均 $54.6 \pm 43.7$ 日となり，化学療法施行 症例で平均 $79.6 \pm 45.2$ 日, 化学療法非施行症例で平 均 $23.3 \pm 4.0$ 日の結果を得た. 一方, osteolytic type の 6 症例のVDT は最小 17 日, 最大 56 日, 平均 $32.5 \pm$ 15.8 日となり, 化学療法施行症例で 平均 $40.0 \pm 13.8$ 日，非施行症例で平均 $17.5 \pm 0.7$ 日の結果となった (表 2). 一般に, osteolytic type に比べ osteosclerotic type のVDT の方が長い傾向がうかがわれる.

肺転移発見時に，すでに肺転移結節が複数の症例で は，各転移結節の径はほぼ同大であり，各々のVDT。 TDT は近似的な值をとり，乙れらの各転移結節はお そらく一定の期間内に成立したものと推定される.し かし一方, 経過中さらに新たな肺転移結節の発現をみ る症例では，その VDT に多少の変動を認め, 当然 TDT にも差が生じてくる．とのように新たな肺転移 結節が原発巣由来のものか, 先行する肺転移結節由来 のものかどうかは，興味深い所であるが，今後の検討 に待ちたい。

図 2 は横軸に TDT, 棅嚡軸に肺転移結節の直径の 3 乗根対数・倍増数を表している. 各直線上に各々の症 例の原発巣発症・切断施行・肺転移発見の時点を明示 し, osteosclerotic type を太線で, osteolytic type を細線で，また化学療法施行群・非施行群を実線・破 線で示している．四からわかるように，肺転移成立の 時点は，全例とも原発巣発症より以前であり，理論上 原発巣発症より最短 0.15 年, 最長 7.72 年, 平均 2.7 年前に肺転移成立の可能性が考えられ，切断施行時に 
は, 確実に肺転移は成立していたと 考えられる. また osteosclerotic type, osteolytic type を問わず, 破線で示した化学療法非施行群は, 急峻な短い経過をとる傾向にある が, 一方化学療法施行群は一般に長 い緩慢な経過をとっているななかで も osteosclerotic type に著明で ある.との事実は，転移に対しての 化学療法による VDT の延長の結 果, TDT が延長したと考えられ， 化学療法による効果と推定せざるを 得ない. その効果は osteosclerotic type の骨肉腫肺転移巣に著明であ $り$, osteosclerotic type の骨肉腫 肺転移巣は化学療法により反応しゃ すいと思われる。

\section{ま と め}

今回, 肺転移をきたした骨肉腫 15 症例を対象に, Collins の Chart, Wollin の数式より, VDT・TDT を算定した。

その結果, VDT は一般に osteolytic type に比べ, osteosclerotic type の方が長く, 肺転移に対し化 学療法を受けた症例が，そうでない 症例より著しく延長している.肺転 移発見時の TDT は 0.86 年から 8.15 年の間に分布し, 平均 3.32 年 で, 肺転移は原発策発症より平均 2.7 年前に成立していると 推定され る.

Collins は，腫瘍の肺転移結節が一定の割合の指数 関数的増殖を行うという仮定のもとに，VDT を設定 した．肺転移笨の増殖は，乙の他自己免疫学的因子や 原発巣の治療などの多くの内的外的要因も考慮しなけ ればならぬが，臨床的に肺転移腫瘍の増殖度を推定す ろうえでは，Collins の方法は一応有用な手段と思わ れる。
表 2

\begin{tabular}{|c|c|c|c|c|c|c|}
\hline \multirow{11}{*}{$\begin{array}{l}\text { 造 } \\
\text { 骨 } \\
\text { 性 }\end{array}$} & \multirow{2}{*}{ No } & \multirow{2}{*}{ VDT } & \multicolumn{3}{|c|}{ T DT } & \multirow{2}{*}{ Chomothorapy } \\
\hline & & & 甡症時 & 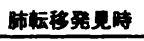 & 死亡時 & \\
\hline & 1 & 21日 & 0.15年 & 1.52 年 & 4.29年 & palliativo \\
\hline & 3 & 23 & 1. 16 & 1.64 & 1.95 & " \\
\hline & 4 & 20 & 0.74 & 1.43 & 1.72 & " \\
\hline & -6 & 29 & 1.99 & 2.15 & 2. 58 & _"- \\
\hline & 7 & 104 & 7.55 & 7.88 & 8.25 & active \\
\hline & 10 & 50 & 3.18 & 3.86 & 4.45 & " \\
\hline & 13 & 121 & 7.72 & 8.15 & 9.42 & " \\
\hline & 14 & 108 & 7.63 & 8.05 & 9.15 & $"$ \\
\hline & 15 & 15 & 0.64 & 0.86 & 1.39 & II \\
\hline
\end{tabular}

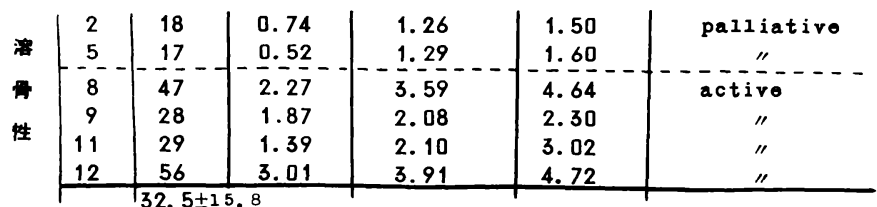

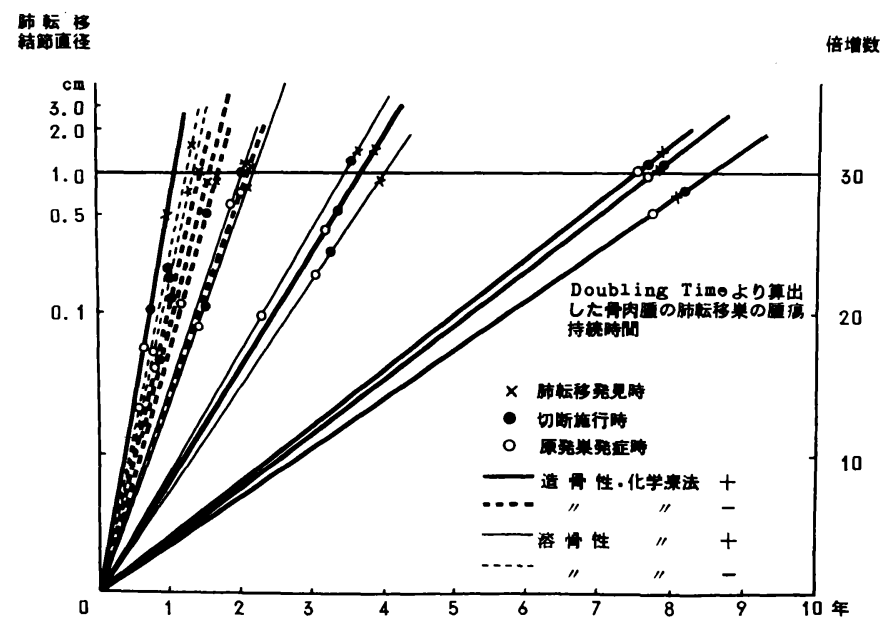

図 2

\section{参考 文 献}

1) Collins, V. P.: Amer. J. Roentgenol. 76, 988-1000, 1956.

2) Garland, L. H.: Cancer. 16, 694-707, 1965.

3) 後藤 守.ほか：臨床整形外科. 第 4 巻, 第 4 号, 254-262, 1969.

4）石井清一・ほか：日本整形外科会 雑誌。第47 巻，第12号，1153-1155，1973. 